\title{
Supply chain collaboration and integration enhance the response of fast-moving consumer goods manufacturers and retailers to customer's requirements
}

\begin{tabular}{|c|c|}
\hline \multicolumn{2}{|l|}{$\begin{array}{l}\text { Authors: } \\
\text { Ken Mathu }{ }^{1} \\
\text { Selepe Phetla }\end{array}$} \\
\hline \multicolumn{2}{|c|}{$\begin{array}{l}\text { Affiliations: } \\
{ }^{1} \text { Gordon Institute of Business } \\
\text { Science, University of } \\
\text { Pretoria, South Africa }\end{array}$} \\
\hline \multicolumn{2}{|c|}{$\begin{array}{l}\text { Corresponding author: } \\
\text { Ken Mathu, } \\
\text { mathuk@gibs.co.za }\end{array}$} \\
\hline \multicolumn{2}{|c|}{$\begin{array}{l}\text { Dates: } \\
\text { Received: } 16 \text { Mar. } 2017 \\
\text { Accepted: } 28 \text { Nov. } 2017 \\
\text { Published: } 08 \text { Aug. } 2018\end{array}$} \\
\hline \multicolumn{2}{|c|}{$\begin{array}{l}\text { How to cite this article: } \\
\text { Mathu, K. \& Phetla, S., 2018, } \\
\text { 'Supply chain collaboration } \\
\text { and integration enhance the } \\
\text { response of fast-moving } \\
\text { consumer goods } \\
\text { manufacturers and retailers } \\
\text { to customer requirements', } \\
\text { South African Journal of } \\
\text { Business Management 49(1), } \\
\text { a192. https://doi.org/ } \\
\text { 10.4102/sajbm.v49i1.192 }\end{array}$} \\
\hline \multicolumn{2}{|c|}{$\begin{array}{l}\text { Copyright: } \\
\text { (C) 2018. The Authors. } \\
\text { Licensee: AOSIS. This } \\
\text { is licensed under the } \\
\text { Creative Commons } \\
\text { Attribution License. }\end{array}$} \\
\hline \multicolumn{2}{|c|}{ Read online: } \\
\hline 口if: & $\begin{array}{l}\text { Scan this QR } \\
\text { code with your } \\
\text { smart phone or } \\
\text { mobile device } \\
\text { to read online. }\end{array}$ \\
\hline
\end{tabular}

Supply chain management has a critical role in steering business success through coordinated activities of the value chain partners. The success of fast-moving consumer goods companies (FMCGs) has a direct relationship with the performance of the leading retailers, which are their main channel of distribution. The supply chain of the leading South African food FMCGs and the corresponding retail chain stores was studied with the aim of establishing that collaboration and integration enhanced the response to the customers' requirements. The study was grounded on collaboration and integration theory, and a qualitative research methodology was used. Non-probability sampling was used, and senior managers selected from the two types of firms were interviewed. The data collected was transcribed, coded and thematically interpreted using content analysis. The outcome of the study indicated that supply chain collaboration and integration of the FMCG retailers, enhanced response to the customers' requirements.

\section{Introduction}

The business environment has become more competitive with the complexity of suppliercustomer relationships, globalisation and a demand-driven approach that requires agile and resilient supply chains (Linton 2013). Organisations apply various initiatives to improve their supply chains' performance in meeting market or customer requirements. The lean and agile types of supply chain initiatives are perceived to be at the forefront in improving supply chain performance (Konecka 2010). The South African packaged-food industry's fast-moving consumer goods companies (FMCGs), and the leading retailers that have a network of stores across the country, operate complex and highly competitive supply chains (Fastmoving Newsletter 2017). The entry of Walmart, the leading US global retailer, into the South African market through a merger with one of the leading local FMCG retail chain stores, Massmart, has exacerbated competition in retail business (Forbes 2011). The food retailers in this context refer to stores trading as general dealers, supermarkets and hypermarkets that contributed close to $5.6 \%$ to South Africa's growth domestic product (GDP) (Stats SA 2015).

The objective of this study was to establish that supply chain collaboration (SCC) enhanced FMCGs and retailers' response to customer requirements. Thus, the problem statement looked at how a collaborative relationship enhanced the delivery of products or services to customers. Literature from the leading supply chain and operations journals, the latest supply chain and operations books, and the global supply chain authority body (the Supply Chain Council) was consulted. The study was underpinned by the theory of collaboration and integration.

\section{Theory of collaboration and integration}

This study is cognisant of the field of collaboration that stipulates 'the relationship between individual participants' self-interest and the collective interests of all involved in the collaborative alliance' (Wood \& Gray 1991). The auspices under which collaboration is convened and the role of convener are expressed by collaborative planning, forecasting and replenishment (CPFR). The CPFR concept was developed by the US association known as 'Voluntary Inter-industry Commerce Solutions' and adopted by the Council of Supply Chain Professionals (Wisner, Tan \& Leong 2016:150). CPFR is defined as:

A concept that aims to enhance supply chain integration by supporting and assisting joint practices. CPFR seeks cooperative management of inventory through joint visibility and replenishment of products 
throughout the supply chain. Information shared between suppliers and retailers aids in planning and satisfying customer demands through a supportive system of shared information. This allows for continuous updating of inventory and upcoming requirements, essentially making the end-to-end supply chain process more efficient. Efficiency is also created through the decrease expenditures for merchandising, inventory, logistics, and transportation across all trading partners. (Wisner et al. 2016:150/1)

This theoretical perspective is the underpinning principle of an effective and efficient supply chain of food FMCGs and retail chain stores in this study.

\section{Background of the study}

The retail space has become highly competitive globally, as consumers are continuously searching for better service, better products and lower prices (Hübner, Kuhn \& Sternbeck 2013). A survey in South Africa conducted by Supply Chain Foresight found three top priorities shared by South African business executives and supply chain managers: the need to increase margins (increase prices and reduce costs), the need to increase supply chain competitiveness, and the need to increase flexibility and responsiveness (Barloworld Logistics 2014). These priorities were linked to the outcomes from lean or agile supply chain initiatives. Retail research established variations in business approach among the retailers between 2009 and 2013; for instance Shoprite Holdings operated on profit margins averaging $3.6 \%$, while Pick n Pay profit margins averaged 1.5\% (Marketline 2014).

Supply chain performance has become a critical factor in business success, and its improvement has become a focus for several firms (Huo et al. 2014). Relationship building for cooperation among supply chain partners is key to this aspect. Lean and resilient (agile) supply chain practices are being implemented by various firms to improve the supply chain performance as companies compete more through the effectiveness and efficiency of their supply chains (Cabral, Grilo \& Cruz-Machado 2012). In this instance, three supply chain (SC) terms are stipulated: lean - balancing quality and response without sacrificing quantity objectives; resilient the ability to return to a position of equilibrium after experiencing some form of deviation from expectations; and agile - the ability to respond quickly to unpredictable changes in customer needs by reconfiguring operations. These terms have been combined in a new SC term, 'leagile' (APICS 2013:90). Thus, supply chain agility is defined as the ability of the value chain to cope with unplanned interruptions to demand and supply (Scholten, Scott \& Fynes 2014). Lean supply chain initiatives use the lean concepts of reduction of non-value-adding activities to eliminate waste, reduce costs and shorten the supply chain lead times (Carvalho, Duarte \& Machado 2011).

A proposition by Hallavo (2015) stated that enterprises that operated in high uncertainty environments required a highly agile capability, whereas those in low uncertainty environments needed to focus on being more efficient.
The author further expressed that enterprises should focus on being more agile in order to be flexible or focus on being lean so as to be more efficient.

In pursuance of the study objectives, the critical issues underpinning a successful supply chain were listed, reviewed in the literature and interrogated from the FMCGs and the retail chain stores. The list comprised SC visibility and collaboration, SC integration and collaboration, SC management and supply chain operating reference (SCOR) model, lean and just-in-time (JIT) management, demandpull SC, transport and warehousing, and customer relationship management (CRM). This list provided the pillars or framework of this study.

\section{Supply chain visibility and collaboration}

Visibility initiatives are activities observed by both upstream and downstream markets that increase the level, frequency and quality of information shared in the supply chain internally and externally. Improved sharing of information between supply chain partners increases the ability to preempt changes and also to recognise changes much earlier (Qrunfleh \& Tarafdar 2013).

Collaborative initiatives, as in inventory management, support the time-based logistics aimed at reducing reliance on forecasting and apply the more reliable JIT process of inventory management and other supply chain processes. The collaborative process requires cooperation and information sharing among the value chain partners (Pienaar \& Vogt 2012:244). This enhances supply chain visibility under the auspices of CPFR (Hollmann, Scavarda \& Thomé 2015). Collaboration in a supply chain is able to increase responsiveness, agility and reduction of inventories across the entire supply chain. That includes lower inventories across the linked suppliers and their suppliers' suppliers, manufacturers and customers and their customers' customers (APICS 2013:28). The CPFR concept enables supply chain partners to work together and jointly develop plans, share forecasts, schedule production and replenishment plans in order to increase end-customer service levels, reduce costs and inventories (Wisner et al. 2016:528). The South African food FMCGs and the leading retailers use CPFR systems through their network of warehouses and distribution centres (DCs) to maintain optimum stock levels at the retail outlets nationally.

\section{Supply chain integration and supply chain collaboration}

Supply chain integration (SCI) and SCC are critical components in a successful supply chain. According to the American Production and Inventory Control Society (APICS), integration is 'the alignment and interlinking of business processes, when supply chain partners interact at all level[s] to maximise mutual benefits' (APICS 2013:172). The same supply chain professional body defines SCC as 'the establishment of working relationship with a supplier 
organisation, whereby two organisations act as one' (APICS 2013:171) and Mangan et al. (2012:49) describe it as 'a relationship built over time'.

\section{Supply chain management and supply chain operating reference model}

Supply chain management is defined as:

The design, planning, execution, control, and monitoring of supply chain activities with the objectives of creating net value, building a competitive infrastructure, leveraging logistics, synchronising supply with demand, and measuring performance. (APICS 2013:172)

Performance measurement and improvement is critical to achieve supply chain goals, and supply chain professionals focus on developing measurement metrics and implementing various improvement initiatives to attain better performance (Hallavo 2015; Johnston \& Clark 2008). A number of supply chain management models have been explored, and the most accepted standard model is the SCOR model. This model has been developed by various supply chain professionals with input from diverse firms globally, under the guardianship of the Supply Chain Council (Supply Chain Council 2010).

The SCOR model simplifies the understanding of supply chain flows and management thereof by proposing that companies look at the supply chain through key activities: plan, source, make, deliver and return (Supply Chain Council 2010). The SCOR model supports supply chain design and review of materials and information flows as in FMCGs retailers' relationships.

The operational ability of supply chain management pursues the five objectives of operations: cost, speed, quality, flexibility and dependability (Slack et al. 2017:38). In this perspective, cost is the ability to render the business sustainable in finance and operational costs, while speed is the ability to perform tasks quickly in production, delivery and service. Quality is the ability to do things right, flexibility is the ability to change and dependability is the ability to keep promises.

The SCOR model helps supply chain practitioners to achieve customer service level improvement, improved flexibility and responsiveness, cost control, reduced working capital and inventory, planning and risk management, supply chain partner integration and talent management (Supply Chain Council 2010). However, the model dictates that supply chain plans be continuously aligned and reviewed periodically. The SCOR model recommends the supply chain primary performance measures as follows:

- Supply chain reliability: The ability of the supply chain to deliver products as expected, that is, on time, at the specified quality and quantity (Kisperska-Moron \& De Haan 2011).

- Supply chain responsiveness: The time a supply chain takes to perform certain tasks, referred to as the 'lead time' or 'order fulfilment time' (Supply Chain Council 2010). In the case of materials flow between FMCGs and retailers, the lead time refers to the length of time when a retailer orders a quantity of product from the FMCG, until the time the retailer receives the ordered product at the specified location (APICS 2013).

- Supply chain agility: Agility in the supply chain is essentially about the capability and capacity to respond to unplanned changes in demand and supply, and to overcome and respond effectively to unexpected problems and disturbances (Jüttner \& Maklan 2011).

- Supply chain cost management: It entails management costs of operating the end-to-end processes of a supply chain, including labour, materials, storage and handling, and transportation (Elgazzar et al. 2012).

- Supply chain assets management: It involves efficient management and utility of supply chain assets, which include inventories, cash and fixed assets (Elgazzar et al. 2012).

\section{Lean and just-in-time management}

The lean supply chain paradigm supports the SCOR model objectives (Kisperska-Moron \& De Haan 2011). Lean management uses the concept of reduction of non-valueadding activities to eliminate waste and reduce costs. According to APICS (2013:90), lean enterprises entail ‘a group of individuals, functions, and sometimes legally separate but operationally synchronised organisations'. This definition supports the supplier-customer relation pursued in this study pertaining to the SCC.

JIT 'is a philosophy of manufacturing based on planned elimination of all waste and on continuous improvement of productivity' (APICS 2013:88). Just-in-time involves the holistic manufacturing activities responsible for the production of product from the inception stage of design, raw material, delivery, warehousing through distribution to the end customers. This complements the focus of this study, regarding the ability of the supply chain of the FMCGs and the leading retailers' speed in reaching the ultimate customer.

The high dynamics of demand in the supply chains of FMCGs and retailers that have high variability of demand is complex, but it is enabled by the integration of systems between the two enterprises (Hallavo 2015). The CPFR connects the retailer to the DCs, which are connected to the FMCG establishments (Tier 1 suppliers), which in turn are connected to their suppliers (Tier 2 suppliers). The connectivity creates a seamless flow of information among the value chain partners, yielding faster end-to-end response (Wisner et al. 2016).

\section{Demand-pull supply chain}

In a demand-pull supply chain, various inventory levels are set and maintained, and production or resupply only takes place once there has been actual demand for the final product at the end of the value chain (Christopher \& Ryals 2014). An effective demand-pull system is supported by implementing other lean and agile initiatives such as 
visibility, speed (lead time reduction) and lot-size reduction to ensure that only what is required is made or supplied (Vlachos 2015). Hence, implementation of the demand-pull concept is supported by initiatives that reduce lead times and improvement in information visibility and collaboration along the value chain.

\section{Transportation and warehousing}

Transportation and warehousing are critical requirements for the FMCG retailers' supply chain to facilitate the distribution network to all the retail outlets nationally. The transportation role is preferably undertaken by third-party logistics (3PL). APICS (2013) defines 3PL as 'managing all or part of another company's delivery function'. The 3PL firms are usually complemented by the retailers' own transport, to enhance the speed of delivery. Essentially, the transportation function commences from the suppliers' warehouse, through to the FMCGs' warehouse, moving downward to the retailers' DCs, through to the retail outlets. The DCs are integrated with the FMCG suppliers and their outlets via the CPFR system (Hollmann et al. 2015).

Fedorciow (2014) describes transport management with three Cs - communication, collaboration and complexity. In supply chain perspectives, communication implies the realtime information from supply chain partners, collaboration is the relationship among the role players and complexity comprises the various activities and priorities involved.

According to Wisner et al. (2016), a warehouse is perceived as a competitive resource in the value chain, and it is defined as 'an enabler to firms for the storage of their purchases, work-in-progress, finished goods, breakbulk and assembly activities, that in turn can result into better customer service'.

A warehousing process of 'cross docking' hastens delivery of orders by transferring products from the suppliers, on arrival at the receiving bay, straight to another truck at the dispatch bay without being stored at the DC (APICS 2013:37). Cross docking is credited as one of the enablers of moving products faster through the value chain (Arora, Iqbal \& Gidwani 2014). In a cross docking warehouse and DC, bulk products arrive from various suppliers (or locations), are off-loaded and split into small deliveries that are destined for the same customer or location, and are grouped together to create a bulkier delivery (Agustina, Lee \& Piplani 2014). This is a routine occurrence at the DCs of the retailers, as the deliveries are made from the FMCGs' warehouses.

\section{Customer relationship management}

Customer relationship management (CRM) is a marketing philosophy based on putting customers first (APICS 2013). To some extent CRM is related to CPFR, as it involves harnessing people, processes and technology to enhance the interactions and feedback loops between a company and its customers. The process aims to ensure value optimisation for both the company and its customers (Jasti \& Kodali 2015).
The relationship is managed so as to ensure that appropriate products or services, channels and interactions are monitored and improved to create greater customer satisfaction (Chen \& Popovich 2003).

\section{Research scope}

The study covered six of the eight major packaged-food FMCGs and three of the five leading food retail chain stores in South Africa. The major FMCGs are Tiger Brands, Clover, Pioneer, Nestlé, Lactalis (Parmalat), AVI, Pioneer and PepsiCo (Passport 2015). The major food retailers include Shoprite Holdings (with food stores branded as Shoprite, Checkers and U-Save), Pick n Pay Holdings (with food stores branded as Pick n Pay and Boxer), Spar Group, Massmart Holdings (with food stores branded as Makro, Cambridge and Game) and Woolworths. These food retailers had annual sales of R142 billion in 2013 (Marketline 2014).

FMCGs and retailers face supply chain uncertainty challenges of globalisation that demand stringent cost control measures to enable them to offer competitive prices to their customers (Passport 2015). This study looked at the environment in which these enterprises operated and managed to remain competitive.

\section{Problem statement}

The interdependence between food FMCGs and retail chain stores is paramount and crucial for the end users (customers). This study aimed to establish how customers' requirements are met timeously.

\section{Empirical objectives}

The empirical objectives of the study were to ascertain the following:

- whether SCC enhanced the response of food FMCGs and retail chain stores to customer requirements;

- whether SCI enhanced the response of food FMCGs and retail chain stores to customer requirements.

\section{Research methodology and design}

The study pursued a qualitative research methodology to investigate whether SCC and SCI enhanced FMCGs-retailers response to customer requirements. That entailed examining whether SCC and SCI enhanced FMCGs' service to their customers, who are the retail chain stores, and also enhanced retailers' service to their customers, who are the end users of the products or services provided. Lee and Lings (2008) describe qualitative research as 'the researcher's process of generating data in conjunctions with the participants'. That meant generating research data by interviewing respondents. The study also concurred with two factors expressed by Saunders and Lewis (2012) - that qualitative research aimed at 'understanding the purpose of the research, and the contextual assumptions that would guide the research strategy' and 'attaining credibility for the conclusions that 
are presented, as the outcomes of the research must be accepted and plausible'.

The study explored the leading South African food FMCGs and the leading retailers that comprised their main channel of distribution. The collaborative relationship in the supply chain linking the two enterprises was examined to determine the improvement in the provision of products and services to their ultimate customers. The nature of management information required from the two enterprises could only be derived from responsible individuals. Hence, the selected participants were senior managers in the disciplines of supply chains and logistics, distribution and warehousing, procurement and customer service. A non-probability sampling technique was used, as posited by Saunders and Lewis (2012). A total of 16 respondents were interviewed from both industries. There were eight food FMCGs earmarked for the study, and six of them provided participants, a $75 \%$ participation rate. Out of the five leading retail chain stores, three participated (60\% participation rate) and contributed ten respondents.

The purpose of the interview was explained to the respondents before the interview date, as stipulated by Saunders and Lewis (2012). The researcher approached the gatekeepers of the earmarked FMCGs and retailers via e-mail and telephone to arrange for interviews with the respective managers. The value proposition of the study had to be expressed before the gatekeepers allowed access to the prospective managers. The value proposition was establishing whether SCC and SCI enhanced the FMCGs' as well as the retailers' response to their customers' requirements. The selected managers were met, interviews scheduled and the use of a data voice recorder device agreed to. In addition, the use of a questionnaire with semi-structured questions, an interview duration of 1 hour and confidentiality arrangements were explained.

The interview questions related to the inter-relationship between the manufacturers of FMCGs and South Africa's leading food retail chain stores, which are their main distribution channels. They sought to establish the FMCGsretailers distribution network, type of warehousing, transportation mode, supply chain design and technology application. These details were covered in five semistructured questions, which were guided by the literature covered. The questions were reviewed and tested for impact before the interviews. They were sent to five outlets outside the target population, and the responses were reviewed and the questions validated to meet the intended target.

The key points from the interviews were recorded in a field notebook that was later used to compare with the transcribed data, and the literature was reviewed to establish validity and reliability. This was done by comparing the interview data, recorded key points from the interview and the literature covered. The three variables, namely the field notebook, data collected and the literature reviewed, were also the basis for triangulation of the study. Data from the transcribed interviews was recorded, coded and thematically interpreted via content analysis. The themes that emanated from the study are expressed in detail in the outcome of the study, which follows.

\section{Results}

The themes and sub-themes that emanated from the interviews are expressed in Table 1.

The seven themes that emanated from the study included centralised distribution, supplier-customer collaboration, cross docking, product alignment, supply chain network and design, 3PL, 4PL and technology integration, culminating in the findings of the study. The themes also expressed the critical role of supply chain and the implications of the lean and agile initiatives for driving performance effectiveness and efficiency in the value chain partners. The supply chain speed that determined the response time to the market or customers' requirements also emerged through JIT warehousing and agile movement of stock.

The two empirical objectives of the study were established as they featured prominently in the themes. Apparently, all the respondents expressed the view that SCC and SCI of the food FMCGs and the retailers were effective and efficient drivers of performance of the two enterprises. They also shared the view that the use of lean and agile (leagile) initiatives enhanced collaboration and integration into the supply chain.

\section{Empirical Objective 1: Supply chain collaboration enhanced the response of food fast-moving consumer goods companies and the leading food retail chain stores to customers' requirements}

It emerged that collaboration was crucial in streamlining distribution and operations costs of the supply chain. The emphasis placed on the supplier-customer relationship,

TABLE 1: Themes and sub-themes that emerged from the data.

\begin{tabular}{|c|c|}
\hline Themes & Sub-themes \\
\hline Centralised distribution & $\begin{array}{l}\text { - Cost saving } \\
\text { - Efficiency in receiving and dispatching goods } \\
\text { - Convenience in inventory control }\end{array}$ \\
\hline Supplier-customer collaboration & $\begin{array}{l}\text { - Value stream mapping } \\
\text { - Impact on demand planning } \\
\text { - Innovation through product integration } \\
\text { - Strategy alignment }\end{array}$ \\
\hline Cross docking products & $\begin{array}{l}\text { - Direct delivery } \\
\text { - JIT in warehouse management } \\
\text { - Agile movement of stock }\end{array}$ \\
\hline $\begin{array}{l}\text { Ease of documentation and } \\
\text { product alignment }\end{array}$ & $\begin{array}{l}\text { - Integration with IT systems } \\
\text { - CPFR } \\
\text { - Bar coding and RFID use }\end{array}$ \\
\hline $\begin{array}{l}\text { Supply chain network, design } \\
\text { and flexibility }\end{array}$ & $\begin{array}{l}\text { - SKU reduction } \\
\text { - SC performance enhancement } \\
\text { Ease of supply chain control } \\
\text { - SC quality and safety } \\
\text { - S \& OP alignment }\end{array}$ \\
\hline $3 \mathrm{PL} / 4 \mathrm{PL}$ & $\begin{array}{l}\text { - Transport optimisation } \\
\text { - Service level agreement } \\
\text { - Use of GPS }\end{array}$ \\
\hline Technology and integration & $\begin{array}{l}\text { - ERP utilisation } \\
\text { - SCOR application } \\
\text { - Skilling employees }\end{array}$ \\
\hline
\end{tabular}

JIT, just-in-time; CPFR, collaborative planning, forecasting and replenishment; ERP, enterprise resource planning; SCOR, supply chain operating reference; 3PL/4PL, third- or fourth-party logistics; RFID, radio frequency identification; SC, supply chain; SKU, stock keeping unit; 3PL, third logistics transport; $4 \mathrm{PL}$, fourth logistics transport. 
strategy alignment, value stream mapping, CPFR, centralised distribution, cross docking at warehouses and the use of 3PL and 4PL modes of transportation were some of the collaborative attributes expressed by all the participants. In addition, the decision by factories to move inventory to the customers' DCs aimed at enhancing deliveries to the customers. Indeed, that was agile development by the food FMCG factories. This collaborative development emerged from all the respondent interviews, as articulately stated by Respondent 3:

We needed space to house some of the stock at our factories for the stock to be distributed straight from there to our customers and cutting out the leg from distributing from our factories to our own distribution centres then to our customers. By building those warehouses we have managed to cut out one leg of distribution and save those costs. There is a steady increase in customer service given the change of the distribution network that has greatly affected our business. (Respondent 3, Male, Senior Supply Chain Manager)

Similar views were expressed by Respondent 15:

We are trying to centralise ordering as much as possible. We have got centralised replenishments in merchandise; we have got centralised replenishments in liquor, but we do not have centralised replenishments in food. That is starting to change; we are starting to pull a lot of it to the centre at the moment, and in the process of doing so and in the implementation of replenishment systems. (Respondent 15, Male, Trade Marketing Manager)

Ten respondents expressed additional benefits accrued from supplier-customer collaboration as cost reduction, and product or service supply speed. In the words of Respondent 5:

This was also the situation back in the days because our customers as well did not have central distribution areas; the only customer that always had central distribution was retailer $\mathrm{Z}$. But lately you have retailer $\mathrm{X}$ and retailer $\mathrm{Y}$ as well building their own distribution centres and that has actually enabled us to take advantage of this situation where our customers have actually built their own distribution centres; then we are able to reduce costs. (Respondent 5, Female, Logistics Supply Chain Manager)

\section{Empirical Objective 2: Supply chain integration enhanced the response of food fast-moving consumer goods companies and retail chain stores to customers' requirements}

There were indications from the themes that technology played a critical role in enhancing the effectiveness, efficiency and speed in the functions of a supply chain. The importance of technology in the SCC process featured prominently from 11 respondents. The application of information technology, the SCOR model, enterprise resource planning (ERP) and collaborative forecasting planning replenishment (CFPR) constituted a platform for the integration of infrastructure for supply chain management. Technology enhanced the information flow, process speed and time, and enabled resource utilisation, as expressed by Respondent 12:

The fact is that it is not controlled by us. I use that term loosely because we have got to manage our own products. There are a lot of steps along this chain; it can go wrong at the distributor, at the store, in some places where these delays can happen and that is where you will see the product. You cannot have individual elements in this value stream being coordinated by different people. One person needs to be the boss of it; I use that term loosely. One person needs to sit and have a look at what happening from literally the planning, the procurement of the first raw material, until it gets to the customer's shelves. This [is] only possible through the connectivity of the levels and technology processes involved. That integration of the entire value stream is critical for the supply chain. (Respondent 12, Male, Information Technology [IT] Specialist, 30 years)

The advent of CFPR has revolutionised the retail business through effective and efficient integration of the focusing process and inventory replenishment, in overcoming the outof-stock situation. The system increases the product visibility and replenishment speed, ensuring stock availability at all times. The technology rendered the supply chain agile and benefited the enterprises and the customers. This was reaffirmed by remarks from Respondent 8:

In some cases, faster moving products moving through the network are going to become a little bit more agile and a little bit more algorithm driven within our warehouse management systems, less about human intervention and more about systems doing the thinking for us. That is definitely going to become a big part of the process and a link between replenishment and what we do within the network is going to be critical. (Respondent 8 , Male, Warehouse Manager, 35 years)

\section{Limitation of the study}

The locally based packaged-food FMCGs operate in high competition among themselves and also compete with importers of food products. The competition is also fierce among the leading retailers, who are their main distribution channel. As a result, these firms are very sensitive about their marketing activities and only divulge information with convincing persuasion. Hence, the researcher spent more time in preparation for the interviews, as the gatekeepers to the industry demanded convincing and strict confidentiality, which was granted. The other aspect was the limited number of leading food FMCGs (eight) and leading food retailers (five) in the nation. The five leading retailers have a network of over 1000 retail stores nationally, but the crucial marketing information is available from their head offices or at some strategic branches, such as the DCs.

\section{Conclusion}

The study explored the supply chain of the eight leading South African packaged-food FMCGs and the five leading food retailers, to establish whether it enhanced response to the customers' requirements. The theory of collaboration and integration on which the study was grounded was reviewed. Extensive literature from leading supply chain and operations management journals, books and websites were reviewed for relevant literature on SCC and integration. A number of topics on collaborative relationships that enhanced product and service delivery were covered. The topics included technology application 
in supply chains with a focus on the SCOR model and CPFR. Other topics included supply chain reliability, responsiveness, agility, cost and asset management, speed, transport and warehousing. The implications of lean and JIT management, demand-pull, transport and warehousing, and CRM were also covered.

The data emanating from the interview was transcribed, coded and analysed under content analysis. The themes that emanated from the data indicated that SCC enhanced the FMCGs retailers' response to customers' requirements.

Subsequently, the two pursued empirical objectives were established as follows:

\section{Empirical Objective 1: Supply chain collaboration enhanced the response of food FMCGs and leading food retailers to customers' requirements}

Collaborative attributes such as supplier-customer relationship, CPFR, strategy alignment, value stream mapping (VSM), lean and JIT, and centralised distribution, among others, were instrumental in rendering faster response to customers' requirements. This information emerged from the themes that emanated from the study as indicated in Table 1.

\section{Empirical Objective 2: $\mathrm{SCl}$ enhanced the response of food FMCGs and leading retailers to customers' requirements}

The themes that emanated indicated that the technology used in the supply chain management of the food FMCGs and leading retailers enhanced the operations in the supply chain, including responding faster to customers' requirements. SCI occurred through supplier-customer connectivity via computer network that facilitated internet use and other application of the SCOR, CPFR and ERP systems.

\section{Recommendations}

Having established that SCC enhanced FMCG retailers' response to customers' requirements, this study recommends a broader study on the holistic benefits accruable by businesses from supply chain management. The study focus would be on resilient supply chains that are lean and agile, which would ultimately culminate into green supply chains that are environmentally friendly. This would be a sustainable supply chain, modelled on the triple-bottom line comprising of economic, social and environmental attributes.

\section{Acknowledgements}

Funding for this study was granted by Gordon Institute of Business Science, South Africa.

\section{Competing interests}

The authors declare that they have no financial or personal relationships which may have inappropriately influenced them in writing this article.

\section{Authors' contributions}

S.P. collected the data through his MBA research at Gordon Institute of Business Science. K.M. articulated the storyline, added literature, modified the methodology, referencing and abstract, and articulated the objectives and the findings of the study.

\section{References}

Agustina, D., Lee, C.K.M. \& Piplani, R., 2014, 'Vehicle scheduling and routing at a crossdocking center for food supply chains', International Journal of Production Economics 152, 29-41. https://doi.org/10.1016/j.ijpe.2014.01.002

American Production and Inventory Control Society (APICS), 2013, The essential supply chain reference, APICS Dictionary, APICS, Chicago, IL.

Arora, S.N., Iqbal, S.A. \& Gidwani, G.D., 2014, 'Cross-docking: A strategy to enhance supply chain agility', International Journal of Logistics \& Supply Chain Management Perspectives 3(3), 1115 .

Barloworld Logistics, 2014, 2014 Supply chain foresight: The rise and fall of customers and companies, Barloworld Logistics, Johannesburg, South Africa, viewed 16 October 2016, from http://www.barloworld-logistics.com/wp-content/uploads/ 2014/03/Supplychainforesight-Report-2014.pdf

Cabral, I., Grilo, A. \& Cruz-Machado, V., 2012, 'A decision-making model for Lean, Agile, Resilient and Green supply chain management', International Journal of Production Research 50(17), 4830-4845. https://doi.org/10.1080/00207543.2012.657970

Carvalho, H., Duarte, S. \& Machado, V.C., 2011, 'Lean, agile, resilient and green: Divergencies and synergies', International Journal of Lean Six Sigma 2(2), 151-179. https://doi.org/10.1108/20401461111135037

Chen, I.J. \& Popovich, K., 2003, 'Understanding customer relationship management (CRM) People, process and technology', Business Process Management Journal 9(5), 672-688. https://doi.org/10.1108/14637150310496758

Christopher, M. \& Ryals, L.J., 2014, 'The supply chain becomes the demand chain', Journal of Business Logistics 35(1), 29-35. https://doi.org/10.1111/jbl.12037

Elgazzar, S., Tipi, N., Hubbard, N. \& Leach, D., 2012, 'Linking supply chain processes' performance to a company's financial strategic objectives', European Journal of Operational Research 223(1), 276-289. https://doi.org/10.1016/j.ejor.2012.05.043

Fastmoving Newsletter, 2017, Food \& beverage suppliers in South Africa, viewed 01 May 2017, from http://www.fastmoving.co.za/fmcg-suppliers/food-9

Fedorciow, B., 2014, The three Cs of transport management: Communication, collaboration, and complexity - Supply Fest June 2014, a retrospect, Eyesight, viewed 07 May 2017, from https://eyefreight.com/the-three-cs-of-transportmanagement-communication-collaboration-and-complexity/

Forbes, 2011, Wal-Mart takes on Africa with Massmart, viewed 01 May 2017, https:// www.forbes.com/sites/greatspeculations/2011/06/10/wal-mart-takes-on-africawith-massmart/\#25918ebb16f9

Hallavo, V., 2015, 'Superior performance through supply chain fit: A synthesis', Supply Chain Management: An International Journal 20(1), 71-82. https://doi org/10.1108/SCM-05-2014-0167

Hollmann, R.L., Scavarda, L.F. \& Thomé, A.M.T., 2015, 'Collaborative planning, forecasting and replenishment: A literature review', International Journal of Productivity and Performance Management 64(7), 971-993. https://doi. org/10.1108/IJPPM-03-2014-0039

Hübner, A., Kuhn, H. \& Sternbeck, M., 2013, 'Demand and supply chain planning in grocery retail: An operations planning framework', International Journal of Retail \& Distribution Management 41(7), 512-553. https://doi.org/10.1108/ IJRDM-05-2013-0104

Huo, B., Qi, Y., Wang, Z. \& Zhao, X., 2014, 'The impact of supply chain integration on firm performance: The moderating role of competitive strategy', Supply Chain Management: An International Journal 19(4), 369-384. https://doi.org/10.1108/ SCM-03-2013-0096

Jasti, N.V.K. \& Kodali, R., 2015, 'A critical review of lean supply chain management frameworks: Proposed framework', Production Planning \& Control 26(13), 1051-1068. https://doi.org/10.1080/09537287.2015.1004563

Johnston, R. \& Clark, G., 2008, Service operations management: Improving service delivery, 3rd edn., Pearson Education, Essex, England.

Jüttner, U. \& Maklan, S., 2011, 'Supply chain resilience in the global financial crisis: An empirical study', Supply Chain Management: An International Journal 16(4), 246-259. https://doi.org/10.1108/13598541111139062

Kisperska-Moron, D. \& De Haan, J., 2011, 'Improving supply chain performance to satisfy final customers: "Leagile" experiences of a polish distributor', International Journal of Production Economics 133(1), 127-134. https://doi.org/10.1016/j. ijpe.2009.12.013

Konecka, S., 2010, 'Lean and agile supply chain management concepts in the aspect of risk management', LogForm Journal, viewed 01 May 2017, from http://www. logforum.net/pdf/6_4_3_10.pdf

Lee, N. \& Lings, I., 2008, Doing business research: A guide to theory and practice, Sage, London.

Linton, M., 2013, Demand-driven supply chains are in demand, viewed 01 May 2017, from http://www.industryweek.com/supplier-relationships/demand-driven-supplychains-are-demand 
Mangan, J., Lalwani, C., Butcher, T. \& Javadpour, R., 2012, Global logistics and supply chain management, John Wiley, West Sussex, UK.

Marketline, 2014, Food retailing in South Africa, (Industry Profile 0044-2058), MarketLine, viewed 01 May 2017, from http://0-advantage.marketline.com. innopac.up.ac.za/Product?pid=MLIP1313-0043

Passport, 2015, Packaged food in South Africa - Industry overview, Euromonito International, viewed 01 May 2017 , from http://www.portal.euromonitor.com. innopac.up.ac.za/portal/analysis/tab

Pienaar, W.J. \& Vogt, J.J., 2012, Business logistics management: A value chain perspective, 4th edn., Oxford University Press, Cape Town, South Africa.

Qrunfleh, S. \& Tarafdar, M., 2013,' Lean and agile supply chain strategies and supply chain responsiveness: The role of strategic supplier partnership and postponement', Supply Chain Management: An International Journal 18(6), 571-582. https://doi.org/10.1108/SCM-01-2013-0015

Saunders, M. \& Lewis, P., 2012, Doing research in business and management, Pearson Education Limited, Essex, England.

Scholten, K., Scott, P. \& Fynes, B., 2014, 'Mitigation processes-antecedents for building supply chain resilience', Supply Chain Management: An International Journal 19(2), 211-228. https://doi.org/10.1108/SCM-06-2013-0191
Slack, N., Brandon-Jones, A., Johnston, R., Singh, H. \& Phihlela, K., 2017, Operations management: Global and Southern Africa perspectives, 3rd edn., Pearsons Education, Cape Town.

STATSSA, 2015, Gross domestic product: Fourth quarter 2014, (Statistical Release No. P0441), Statistics South Africa, Pretoria, viewed 01 May 2017, from http://www. statssa.gov.za/publications/P0441/P04414thQuarter2014.pdf

Supply Chain Council, 2010, Supply Chain Council issues a new version of SCOR model, viewed 14 April 2017, from http://www.supplychainbrain.com/content/ general-scm/education-professional-development/single-article-page/article/ supply-chain-council-issues-new-version-of-scor-model/

Vlachos, I., 2015, 'Applying lean thinking in the food supply chains: A case study' Production Planning \& Control 26(16), 1351-1367. https://doi.org/10.1080/0953 7287.2015 .1049238

Wisner, J.D., Tan, K.-C. \& Leong, G.K., 2016, Principles of supply chain management: A balanced approach, 4th edn., Cengage Learning, Boston, MA.

Wood, D.J. \& Gray, B., 1991, 'Towards the comprehensive theory of collaboration' The Journal of Applied Behavioral Science, viewed 05 April 2017, from http://journals.sagepub.com/doi/abs/10.1177/0021886391272001?journalCo de=jaba 